\title{
STUDI PERUBAHAN KINERJA PELAKU RITEL DAN POLA BELANJA KONSUMEN PADA PUSAT PERBELANJAAN SEKITAR PASCA OPERASIONALISASI MALL BINTARO XCHANGE (STUDI KASUS BINTARO PLAZA DAN LOTTE MALL)
}

\author{
Thyoria Mariska Girsang ${ }^{1}$, Nasiruddin Mahmud ${ }^{2}$, Erwin Fahmi ${ }^{3}$ \\ ${ }^{1}$ Alumni Magister Teknik Perencanaan, Universitas Tarumanegara, Jakarta \\ Email: girsang.riska@yahoo.com \\ ${ }^{2)}$ Dosen Magister Perencanaan, Universitas Tarumanegara, Jakarta \\ ${ }^{3)}$ Dosen Magister Perencanaan, Universitas Tarumanegara, Jakarta
}

\begin{abstract}
ABSTRAK
Bintaro Xchange Mall yang beroperasi pada akhir tahun 2013, merupakan pusat perbelanjaan terbaru, terbesar, dan paling strategis di kawasan Bintaro Jaya. Sebelum ke Bintaro Xchange Mall, 2 pusat perbelanjaan serupa beroperasi di kawasan Bintaro Jaya, yaitu Bintaro Plaza dan Lotte Mall. Kehadiran Bintaro Xchange Mall diindikasikan berimbas pada perubahan kinerja ritel di pusat perbelanjaan yang ada serta perilaku belanja konsumen. Studi teoritis menjelaskan bahwa ada 12 faktor yang menentukan keberhasilan pusat perbelanjaan. Penelitian ini bertujuan untuk mengeksplorasi perubahan kinerja ritel dan perilaku belanja konsumen, dan bagaimana hal ini berkaitan dengan persepsi konsumen terhadap faktor-faktor keberhasilan pusat perbelanjaan. Penelitian ini menggunakan metode kuantitatif dengan teknik analisis komparatif dan korelasi. Hasil penelitian membuktikan bahwa telah terjadi perubahan kinerja pengecer dan perilaku belanja konsumen di Bintaro Plaza dan Lotte Mall pasca operasionalisasi Bintaro Xchange Mall. Hasil analisis korelasi menunjukkan bahwa perubahan kinerja ritel berpengaruh signifikan terhadap perubahan perilaku belanja konsumen, sedangkan perubahan perilaku belanja konsumen berkorelasi signifikan dengan persepsi konsumen terhadap 12 aspek pusat perbelanjaan. Oleh karena itu disimpulkan bahwa perubahan kinerja ritel berhubungan secara tidak langsung dengan konsumen yang tanggap pada pusat perbelanjaan.
\end{abstract}

Kata kunci: kinerja ritel, perilaku berbelanja konsumen, pusat perbelanjaan

\section{PENDAHULUAN}

\section{Latar Belakang}

Secara filosofis, manusia sebagai makhluk sosial telah melakukan kegiatan pertukaran (trading) sejak awal peradaban untuk memenuhi kebutuhan hidup. Kegiatan pertukaran yang diawali dengan proses barter, selanjutnya berkembang menjadi kegiatan jual beli dengan menggunakan uang sebagai alat tukar. Saat ini kegiatan belanja merupakan kegiatan konsumsi, rekreasi dan gaya hidup yang telah menjadi bagian dari keseharian manusia untuk memenuhi kebutuhan hidupnya.

Sebagai wadah kegiatan belanja, keberadaan pusat perbelanjaan saat ini menjadi salah satu fungsi penting dalam pengembangan perkotaan. Menurut Maitland (1987), pusat perbelanjaan adalah suatu tempat dengan inti satu atau beberapa department store besar sebagai daya tarik ritel-ritel kecil dan rumah makan yang menghadap ke koridor utama atau jalur sirkulasi dan ruang komunal bagi interaksi antar pengunjung dan pedagang. Dewasa ini, pusat perbelanjaan bukan hanya tempat membeli produk atau jasa, tetapi juga sebagai tempat melihat-lihat, bersenang-senang, rekreasi, bersantai dan bersosialisasi. Pusat perbelanjaan telah berevolusi dari asalnya sebagai pusat konsumsi beralih menjadi aspirasi dan gaya hidup konsumen. Bukan hanya sebatas tempat untuk melakukan pembelian produk saja, akan tetapi telah berubah fungsi menjadi tempat rekreasi yang menarik, menyenangkan, aman, nyaman, dan dapat dipercaya (Neo dan Wing, 2005).

Pengembangan perkotaan tidak hanya tentang penciptaan zona aman dan terjamin, namun juga penciptaan jiwa dari sebuah kota. Dalam hal ini pusat perbelanjaan memainkan peran penting dalam 
DAN POLA BELANJA KONSUMEN PADA PUSAT

PEMBELANJAAN SEKITAR PASCA OPERASIONAL

MALL BINTARO XCHANGE

bentuk inovasi, desain dan pendekatan (Ghei, 2012). Beberapa penelitian seringkali menyebut mall dan pertokoan sebagai ruang publik secara sepintas (Stillerman \& Salcedo, 2012). Dalam studi tersebut, peneliti secara eksplisit menerima mall sebagai ruang publik baru. Fachran (2016) menyebutkan bahwa dalam peradaban modern, eksistensi pusat perbelanjaan modern sering menjadi simbol dari kemajuan sebuah kota. Keberadaan pusat perbelanjaan modern telah menjadi salah satu penanda bagi peradaban kota modern.

Di masa Indonesia modern, perkembangan perumahan skala besar (yang biasa disebut kawasan kota baru) sudah dimulai dari pengembangan Kawasan Menteng pada 1920-an. Dilanjutkan dengan pengembangan Kawasan Kebayoran Baru pada 1940-an, pengembangan Kawasan Tebet pada 1960an, dan perumahan di hinterland Jakarta (Tangerang, Bekasi dan Bogor) pada akhir 1970-an, baik oleh Perum Perumnas sebagai pengembang pemerintah maupun pengembang swasta lainnya. Kawasan Bintaro Jaya merupakan salah satu kawasan kota baru di Indonesia yang telah dikembangkan sejak tahun 1979. Kawasan Bintaro Jaya dikembangkan oleh PT. Jaya Property (yang sebelumnya bernama PT. Bintaro Jaya) di atas lahan seluas 1.000 hektar. Secara administratif, Kawasan Bintaro Jaya terletak di Kota Tangerang Selatan (sebelumnya Kabupaten Tangerang), sebagai kawasan hinterland DKI Jakarta.

Dengan konsep kota mandiri dan modern, maka Kawasan Bintaro Jaya sebagai kawasan permukiman dilengkapi dengan berbagai fungsi komersial dan fasilitas pendukungnya. Sebagai fungsi komersial, di Bintaro Jaya terdapat beberapa pusat perbelanjaan yang telah dikembangkan dan beroperasi, yaitu Bintaro Plaza (BP), Lotte Mall (LM), dan Mall Bintaro XChange (BXC). Walaupun memiliki kesamaan sebagai pusat perbelanjaan, namun demikian ketiga pusat perbelanjaan tersebut memiliki perbedaan dalam segmentasi dan spesialisasi produk yang ditawarkan.

Mall BXC merupakan pusat perbelanjaan terbaru, terbesar dan paling strategis di Kawasan Bintaro Jaya. Mall BXC diresmikan pada akhir 2013 di atas lahan seluas 25 hektar dan berlokasi di seberang Stasiun Jurang Mangu atau tepat di samping Tol Ulujami-Serpong. Mall BXC memiliki konsep pusat gaya hidup (lifestyle) komunitas dan ekologi, yaitu pusat perbelanjaan dengan berbagai produk fashion, kuliner, gaya hidup, hiburan/rekreasi dan ruang terbuka interaktif. Hal ini berbeda dari pusat perbelanjaan lain di Bintaro Jaya, yang mengusung konsep pusat perbelanjaan umum (Bintaro Plaza) dan pusat belanja serba ada (Lotte Mall).

Atas penjelasan tersebut, maka kehadiran Mall BXC di Kawasan Bintaro Jaya merupakan pusat perbelanjaan yang terakhir dikembangkan untuk melengkapi 2 pusat perbelanjaan sebelumnya, diindikasi kehadiran Mall BXC memiliki dampak terhadap perubahan kinerja ritel pada Bintaro Plaza dan Lotte Mall yang sudah ada sebelumnya. Selain itu, keberadaan Mall BXC juga diindikasi memiliki dampak terhadap perilaku belanja konsumen/pengunjung pusat perbelanjaan. Atas dasar itulah, timbul motivasi peneliti untuk melakukan penelitian terkait perubahan kinerja ritel pada pusat perbelanjaan sekitar (Bintaro Plaza dan Lotte Mall) pasca operasionalisasi Mall BXC.

\section{Rumusan Masalah}

Di Indonesia, pembangunan pusat perbelanjaan harus mengikuti ketentuan Peraturan Presiden Republik Indonesia Nomor 112 Tahun 2007 tentang Penataan dan Pembinaan Pasar Tradisional, Pusat Perbelanjaan dan Toko Modern. Dalam peraturan tersebut diatur bahwa pendirian pusat 
perbelanjaan dan toko modern wajib memperhatikan jarak antara hypermarket dengan pasar tradisional yang telah ada sebelumnya. Pengaturan jarak tersebut selanjutnya diatur oleh pemerintah daerah dalam Rencana Tata Ruang Wilayah (RTRW), sehingga pengembangan pusat perbelanjaan harus mengacu pada RTRW setempat. Selain itu, harus dilakukan juga analisa kondisi sosial ekonomi masyarakat setempat dan memperhitungkan keberadaan pasar tradisional dan Usaha Mikro Kecil dan Menengah (UMKM) setempat.

Berbagai ketentuan tersebut diatur untuk mengurangi dampak negatif keberadaan pusat perbelanjaan yang dapat saling mematikan, namun dapat memaksimalkan manfaat keberadaan pusat perbelanjaan setinggi-tingginya bagi masyarakat sekitar. Hal ini sejalan dengan hasil penelitian Farchan (2016), yang menyatakan bahwa pembangunan pusat perbelanjaan memiliki dampak bagi lingkungan di sekitarnya, baik positif maupun negatif. Dampak pembangunan pusat perbelanjaan diantaranya memberikan tekanan pada usaha ritel sekitar dan memberikan rangsangan pola konsumsi masyarakat.

Atas penjelasan permasalahan tersebut, maka dapat dirumuskan pertanyaan penelitian sebagai berikut:

1. apakah terjadi perubahan kinerja ritel pada pusat perbelanjaan sekitar (Bintaro Plaza dan Lotte Mall) pasca operasionalisasi BXC?

2. apakah terjadi perubahan perilaku belanja konsumen pusat perbelanjaan sekitar (Bintaro Plaza dan Lotte Mall) pasca operasionalisasi BXC?

3. apakah ada hubungan antara perubahan kinerja ritel pada pusat perbelanjaan dengan perubahan pola berbelanja konsumen?

4. apakah ada hubungan antara perubahan pola berbelanja konsumen dengan penilaian konsumen terhadap pusat perbelanjaan

\section{Tujuan}

Tujuan penelitian ini adalah untuk menelusuri bagaimana perubahan kinerja riteldan bagaimana perubahan pola belanja konsumen pada pusat perbelanjaan sekitar (Bintaro Plaza dan Lotte Mall)pasca operasionalisasi Mall BXC serta bagaimana hubungan antara perubahan kinerja ritel dengan perubahan pola belanja konsumen dan penilaian konsumen terhadap pusat perbelanjaan

\section{METODE PENELITIAN}

Jenis penelitian ini adalah penelitian kuantitatifdengan survei lapangan untuk pengumpulan data dan deskriptif analisis dalam merumuskan hipotesis yang disusun berdasarkan fenomena awal, kajian teoritis dan konstruksi variabel penelitian. Variabel penelitian terdiri dari variabel penilaian konsumen terhadap pusat perbelanjaan, variabel perubahan pola belanja konsumen, dan variabel perubahan kinerja ritel. Responden dalam peneltian ini akan diminta untuk menilai aspek-aspek dari obyek penelitian ini, yaitu Mall BXC, Bintaro Plaza dan Lotte Mall Bintaro. Penilaian konsumen terhadap pusat perbelanjaan yang bersifat perseptif, dilakukan menggunakan skala likert 1 (sangat tidak baik) hingga 4 (sangat baik) untuk setiap aspek. Responden dalam penelitian ini meliputi (i) pelaku ritel, yaitu Bintaro Plaza dan Lotte Mall; dan (ii) konsumen (pengunjung) Bintaro Plaza, Lotte Mall dan Mall BXC. Penentuan sampel dilakukan menggunakan metode proportionate random sampling, dengan jumlah sampel sebagai berikut: 
Tabel 1. Responden Penelitian

\begin{tabular}{|c|l|l|c|}
\hline No & \multicolumn{1}{|c|}{ Nama Responden } & \multicolumn{1}{|c|}{ Populasi } & Sampel \\
\hline 1 & Pelaku ritel dari Bintaro Plaza & 135 tenant & 44 \\
\hline 2 & Pelaku ritel dari Lotte Mall & 73 tenant & 24 \\
\hline 3 & Konsumen (pengunjung) Mall BXC & 21.000 orang & 47 \\
\hline 4 & Konsumen (pengunjung) Bintaro Plaza & 15.000 orang & 33 \\
\hline 5 & Konsumen (pengunjung) Lotte Mall & 9.000 orang & 20 \\
\hline
\end{tabular}

\begin{tabular}{|c|c|c|}
\hline $\begin{array}{l}\text { SISI PELAKU RITEL } \\
\text { (DARI } 2 \text { MALL) }\end{array}$ & & $\begin{array}{l}\text { SISI KONSUMEN } \\
\text { (DARI } 3 \text { MALL) }\end{array}$ \\
\hline $\begin{array}{l}\text { Variabel Perubahan } \\
\text { Kinerja Ritel }\end{array}$ & $\leftarrow$ & \multirow{2}{*}{$\begin{array}{l}\text { Variabel Penilaian Konsumen terhadap Pusat } \\
\text { Perbelanjaan (Lokasi, Visibilitas, Aksesibilitas, } \\
\text { Ukuran, Perencanaan, Desain, Anchor Tenant, Tenancy } \\
\text { Mix, Branding, Marketing, Management, \& Layanan } \\
\text { Konsumen) }\end{array}$} \\
\hline $\begin{array}{l}\text { - Perubahan Intensitas } \\
\text { Pengunjung }\end{array}$ & & \\
\hline $\begin{array}{l}\text { - Perubahan Volume } \\
\text { Penjualan } \\
\text { - Perubahan Omzet } \\
\text { Pelaku Ritel }\end{array}$ & & $\begin{array}{l}\text { Analisis } \\
\text { Korelasi }\end{array}$ \\
\hline \multirow{2}{*}{\multicolumn{2}{|c|}{$\begin{array}{l}\text { Analisis Komparatif (2 Mall) } \\
\text { Analisis Deskriptif }\end{array}$}} & $\begin{array}{c}\text { Variabel Perubahan Pola Belanja Konsumen } \\
\text { (Belanja Harian, Belanja Bulanan, Belanja Pakaian, } \\
\text { Belanja Kuliner, Belanja Lifestyle, \& Belanja Rekreasi) }\end{array}$ \\
\hline & & $\begin{array}{l}\text { - Tetap di Pusat Perbelanjaan Bersangkutan }(0) \\
\text { - Pindah Belanja ke Pusat Perbelanjaan Lain }(-) \\
\text { - Pindah Belanja dari Pusat Perbelanjaan Lain }(+)\end{array}$ \\
\hline
\end{tabular}

Gambar 1. Konstruksi Variabel

Dari hasil konstruksi variabel tersebut di atas, maka dapat dirumuskan hipotesis penelitian sebagai berikut:

a. Hipotesis 1: Terdapat perbedaan yang signifikan antara perubahan kinerja ritel, perubahan pola belanja konsumen dan penilaian konsumen terhadap pusat perbelanjaan, antara di Bintaro Plaza dan Lotte Mall pasca operasionalisasi Mall BXC;

b. Hipotesis 2: Terdapat hubungan yang signifikan antara perubahan kinerja ritel dengan perubahan pola belanja konsumen;

c. Hipotesis 3: Terdapat hubungan yang signifikan antara perubahan pola belanja konsumen dengan penilaian konsumen terhadap pusat perbelanjaan

Pengumpulan data primer difokuskan pada data responden yang meliputi perubahan kinerja ritel dari pelaku ritel pada 2 pusat perbelanjaan sekitar pasca operasionalisasi Mall BXC serta perubahan pola belanja konsumen dan penilaian konsumen terhadap pusat perbelanjaan. Pengumpulan data primer yang dibutuhkan dalam penelitian ini akan diperoleh melalui kuesioner, pengamatan dan dokumentasi, serta wawancara mendalam pada beberapa responden terpilih sesuai kebutuhan. 


\section{HASIL DAN PEMBAHASAN}

\section{Analisis Perubahan Kinerja Pelaku Ritel}

Pelaku ritel yang dimaksud merupakan pelaku ritel pada pusat perbelanjaan terdampak operasionalisasi Mall BXC, yaitu pelaku ritel pada Bintaro Plaza sebanyak 44 responden dan pelaku ritel pada Lotte Mall sebanyak 24 responden. Analisis yang dilakukan pada bagian ini dimaksudkan untuk memahami perubahan kinerja pelaku ritel yang terjadi berdasarkan hasil data kuesioner yang diperoleh menggunakan beberapa pengujian, yang meliputi:

- Analisis signifikansi perubahan, untuk menguji apakah perubahan yang teridentifikasi bersifat signifikan atau tidak. Analisis signifikansi dilakukan menggunakan Uji One-Sample Test terhadap 3 variabel, yaitu: (i) perubahan intensitas pengunjung ritel (Z1); (ii) perubahan volume penjualan ritel (Z2); dan (iii) perubahan omzet pelaku ritel (Z3);

- Analisis perbedaan perubahan (analisis komparatif variabel sebelum-sesudah), untuk menguji apakah perubahan yang terjadi terdapat perbedaan diantara kedua pusat perbelanjaan, yaitu Bintaro Plaza dan Lotte Mall. Analisis ini dilakukan menggunakan teknik Uji Mann-Whitney, yaitu (i) perubahan intensitas pengunjung ritel (Z1); (ii) perubahan volume penjualan ritel (Z2); dan (iii) perubahan omzet pelaku ritel (Z3);

- Analisis deskriptif perubahan kinerja, untuk memperoleh penjelasan deskriptif mengenai perubahan yang terjadi pada kedua pusat perbelanjaan, yaitu Bintaro Plaza dan Lotte Mall pasca operasionalisasi Mall BXC, yang meliputi: (i) perubahan intensitas pengunjung ritel, baik pada Bintaro Plaza dan Lotte Mall; (ii) perubahan volume penjualan ritel, baik pada Bintaro Plaza dan Lotte Mall; dan (iii) perubahan omzet pelaku ritel, baik pada Bintaro Plaza dan Lotte Mall.

Berdasarkan hasil 3 (ketiga) analisis di atas maka didapatkan hasil sebagai berikut:

(a) Dari hasil analisis komparatif diketahui bahwa perubahan kinerja pelaku ritel antara di Bintaro Plaza dan Lotte Mall tidak berbeda secara signifikan, yang berarti perbedaan perubahan kinerja pelaku ritel yang terjadi antara kedua mall tersebut hampir sama;

(b) Sebagian besar pelaku ritel di Lotte Mall $(66,67 \%)$ dan Bintaro Plaza $(68,18 \%)$ menyatakan mengalami penurunan intensitas pengunjung pasca operasionalisasi Mall $\mathrm{BXC}$, dengan ratarata penurunan sebesar $-41,5 \%$ di Lotte Mall dan $-33,8 \%$ di Bintaro Plaza;

(c) Sebagian besar pelaku ritel di Bintaro Plaza $(68,18 \%)$ dan Lotte Mall $(41,67 \%)$ menyatakan mengalami penurunan volume penjualan pasca operasionalisasi Mall $\mathrm{BXC}$, dengan rata-rata penurunan sebesar -31,5\% di Lotte Mall dan sebesar -30,6\% di Bintaro Plaza;

(d) Sebagian besar pelaku ritel di Lotte Mall $(62,50 \%)$ dan Bintaro Plaza $(70,45 \%)$ menyatakan mengalami penurunan omzet pasca operasionalisasi Mall BXC, dengan rata-rata penurunan sebesar -31,2\% di Lotte Mall dan -31,3\% di Bintaro Plaza.

\section{Analisis Komparatif Pola Belanja Konsumen}

Analisis yang dilakukan pada bagian ini dimaksudkan untuk melakukan komparasi dalam perubahan pola belanja konsumen yang terjadi berdasarkan hasil data kuesioner yang diperoleh menggunakan beberapa pengujian, yaitu:

- $\quad$ Analisis Komparatif pola belanja konsumen 3 mall (analisis komparatif variabel 3 mall), untuk menguji apakah perubahan yang terjadi terdapat perbedaan diantara ketiga pusat perbelanjaan, yaitu Bintaro Plaza, Lotte Mall dan Mall BXC. Analisis ini menggunakan Uji Krusikal Wallis, 
yang meliputi: (i) perubahan pola belanja harian konsumen (Y1); (ii) perubahan pola belanja bulanan konsumen (Y2); (iii) perubahan pola belanja pakaian konsumen (Y3); (iv) perubahan pola belanja kuliner konsumen (Y4); (v) perubahan pola belanja lifestyle konsumen (Y5); dan (vi) perubahan pola belanja rekreasi konsumen (Y6);

- Analisis deskriptif perubahan pola belanja konsumen, untuk memperoleh penjelasan deskriptif mengenai perubahan yang terjadi pada ketiga pusat perbelanjaan, yaitu Bintaro Plaza, Lotte Mall dan Mall BXC, yang meliputi perubahan belanja harian, belanja bulanan, belanja pakaian, belanja kuliner, belanja lifestyle, dan belanja rekreasi.

Berdasarkan hasil 2 (kedua)analisis di atas maka didapatkan hasil sebagai berikut:

(a) Dari hasil analisis komparatif diketahui bahwa perubahan pola belanja konsumen antara di Bintaro Plaza, Lotte Mall dan Mall BXC memiliki perbedaan secara signifikan.

(b) Sebagian besar konsumen Lotte Mall $(70,88 \%)$ berpindah belanja ke pusat perbelanjaan lain, yaitu 38,17\% pindah ke Mall BXC dan 32,71\% pindah ke Bintaro Plaza dan lainnya. Hal yang sama terjadi di Bintaro Plaza dimana sebagian besar konsumen (76,30\%) berpindah belanja ke pusat perbelanjaan lain, yaitu 53,91\% pindah ke Mall BXC dan 22,39\% pindah ke Lotte Mall dan lainnya.

(c) Kemampuan Lotte Mall untuk menarik konsumen dari pusat perbelanjaan lain (dari Bintaro Plaza dan lainnya) sebesar 23,96\%. Sedikit lebih rendah terjadi di Bintaro Plaza dimana kemampuan menarik konsumen dari pusat perbelanjaan lain (dari Lotte Mall dan lainnya) sebesar $14,29 \%$.

(d) Hanya sebagian kecil konsumen Lotte Mall $(5,16 \%)$ dan Bintaro Plaza $(9,41 \%)$ yang tidak pindah ke pusat perbelanjaan lain pasca operasionalisasi Mall BXC.

\section{Analisis Penilaian Konsumen terhadap Pusat Perbelanjaan}

Analisis yang dilakukan pada bagian ini dimaksudkan untuk memahami bagaimana konsumen melakukan penilaian terhadap ketiga pusat perbelanjaan (Bintaro Plaza, Lotte Mall dan Mall BXC), untuk menjawab kenapa konsumen pindah ke Mall BXC. Analisis penilaian konsumen terhadap pusat perbelanjaan dilakukan melalui:

- Analisis komparatif, untuk menguji apakah penilaian konsumen yang diberikan konsumen terdapat perbedaan diantara ketiga pusat perbelanjaan. Analisis ini dilakukan menggunakan Uji Kruskal Wallis, yang meliputi: (i) penilaian terhadap lokasi pusat perbelanjaan (X1); (ii) penilaian terhadap visibilitas pusat perbelanjaan (X2); (iii) penilaian terhadap aksesibilitas pusat perbelanjaan (X3); (iv) penilaian terhadap ukuran pusat perbelanjaan (X4); (v) penilaian terhadap perencanaan pusat perbelanjaan (X5); (vi) penilaian terhadap desain pusat perbelanjaan (X6); (vii) penilaian terhadap anchortenant pusat perbelanjaan (X7); (viii) penilaian terhadap tenancymix pusat perbelanjaan (X8); (ix) penilaian terhadap branding pusat perbelanjaan (X9); (x) penilaian terhadap marketing pusat perbelanjaan (X10); (xi) penilaian terhadap management pusat perbelanjaan (X11); dan (xii) penilaian terhadap layanan konsumen pusat perbelanjaan (X12);

- Analisis deskriptif penilaian konsumen, untuk memperoleh penjelasan deskriptif mengenai penilaian yang diberikan pada ketiga pusat perbelanjaan, yaitu Bintaro Plaza, Lotte Mall dan Mall BXC, yang meliputi perubahan belanja harian, belanja bulanan, belanja pakaian, belanja kuliner, belanja lifestyle, dan belanja rekreasi. 
Berdasarkan hasil 2 (kedua) analisis di atas maka didapatkan hasil sebagai berikut:

(a) Dari hasil analisis komparatif diketahui bahwa penilaian terhadap 12 aspek pusat perbelanjaan yang dilakukan konsumen di Bintaro Plaza, Lotte Mall dan Mall BXC memiliki perbedaan yang signifikan;

(b) Mall BXC mendapatkan penilaian paling tinggi untuk semua variabel penilaian konsumen terhadap pusat perbelanjaan (X1-X12) dibanding pada Lotte Mall dan Bintaro Plaza;

(c) Bintaro Plaza menduduki posisi kedua dari semua penilaian konsumen terhadap pusat perbelanjaan, kecuali pada penilaian aspek aksesibilitas (X3) dimana Bintaro Plaza memperoleh penilaian paling rendah;

(d) Lotte Mall menduduki posisi paling rendah dari semua penilaian konsumen terhadap pusat perbelanjaan, kecuali pada penilaian aspek aksesibilitas (X3) dimana Lotte Mall memperoleh penilaian posisi kedua.

\section{Analisis Korelasi}

Analisis korelasi merupakan analisis kuantitatif yang digunakan untuk menguji hubungan antara dua kelompok variabel. Dua variabel dikatakan berkolerasi apabila perubahan pada variabel yang satu akan diikuti perubahan pada variabel yang lain secara teratur dengan arah yang sama (korelasi positif) atau berlawanan (korelasi negatif). Adanya hubungan sebab akibat antara dua variabel harus dapat dijelaskan secara logika. Analisis korelasi dilakukan pada (i) perubahan kinerja ritel dengan perubahan pola belanja konsumen; dan (ii) perubahan Pola Belanja Konsumen dengan Penilaian Konsumen terhadap Pusat Perbelanjaan.

Hasil analisis korelasi antara perubahan kinerja ritel dengan perubahan pola belanja konsumen yang dapat difokuskan yaitu:

(a) Perubahan pola belanja konsumen terbukti memiliki hubungan yang signifikan dengan perubahan intensitas pengunjung ritel, dengan besarnya hubungan sebesar 97,3\% (sangat kuat);

(b) Perubahan pola belanja konsumen tidak terbukti memiliki hubungan yang signifikan dengan perubahan volume penjualan ritel, dimana besarnya hubungan hanya sebesar $65 \%$ (sedang);

(c) Perubahan pola belanja konsumen terbukti memiliki hubungan yang signifikan dengan perubahan omzet pelaku ritel, adapun besarnya hubungan sebesar 98,9\% (sangat kuat).

Sedangkan hasil analisis korelasi antara perubahan pola belanja konsumen dengan penilaian konsumen terhadap 12 aspek pusat perbelanjaan yang dapat difokuskan yaitu:

(a) Perubahan belanja harian konsumen terbukti memiliki hubungan yang signifikan dengan hanya 5 variabel penilaian konsumen pada aspek perencanaan (X5), desain (X6), anchortenant (X7), marketing (X10) dan management (X11) pusat perbelanjaan;

(b) Perubahan belanja bulanan konsumen terbukti memiliki hubungan yang signifikan dengan 6 variabel penilaian konsumen pada aspek ukuran (X4), perencanaan (X5), desain (X6), branding (X9), management (X11) dan layanan konsumen (X12) pusat perbelanjaan;

(c) Perubahan belanja pakaian, belanja kuliner, belanja lifestyle, dan belanja rekreasi konsumen terbukti memiliki hubungan yang signifikan dengan penilaian konsumen pada semua aspek pusat perbelanjaan (lokasi, visibilitas, aksesibilitas, ukuran, perencanaan, desain, anchortenant, tenancymix, branding, marketing, management, dan layanan konsumen). 
DAN POLA BELANJA KONSUMEN PADA PUSAT

PEMBELANJAAN SEKITAR PASCA OPERASIONAL

MALL BINTARO XCHANGE

Berdasarkan hasil analisis yang telah dilakukan tersebut, oleh karena perubahan kinerja pelaku ritel memiliki hubungan dengan perubahan pola belanja konsumen dan perubahan pola belanja konsumen memiliki hubungan dengan penilaian konsumen terhadap 12 aspek pusat perbelanjaan, maka dikatakan bahwa perubahan kinerja pelaku ritel memiliki hubungan tidak langsung dengan penilaian konsumen terhadap 12 aspek pusat perbelanjaan. Atas dasar itu, untuk mendukung keberhasilan kinerja pelaku ritel maka pengembangan suatu pusat perbelanjaan perlu memperhatikan 12 aspek yang meliputi lokasi, visibilitas, aksesibilitas, ukuran, perencanaan, desain, anchortenant, tenancymix, branding, marketing, management, dan layanan konsumen. Dalam konteks pusat perbelanjaan eksisting, untuk beradaptasi dengan perubahan kompetisi pusat perbelanjaan baru, maka perlu dilakukan review dan peningkatan 12 aspek pusat perbelanjaan tersebut.

\begin{tabular}{|c|c|c|}
\hline $\begin{array}{l}\text { Perubahan Kinerja } \\
\text { Pelaku Ritel }\end{array}$ & $\begin{array}{l}\text { Perubahan Pola Belanja } \\
\text { (Pindah ke Mall BXC) }\end{array}$ & $\begin{array}{l}\text { Penilaian Konsumen pada } \\
\text { Mall BXC Lebih Baik }\end{array}$ \\
\hline
\end{tabular}

Gambar2. Skema Hasil Analisis

\section{KESIMPULAN DAN SARAN}

\section{Kesimpulan}

1. Berdasarkan hasil analisis komparatif diketahui bahwa tidak terdapat perbedaan yang signifikan antara Bintaro Plaza dan Lotte Mall, terkait dengan perubahan kinerja ritel sebelum maupun sesudah operasionalisasi BXC. Meskipun berdasarkan hasil temuan lapangan dan analisis diketahui bahwa terjadi penurunan kinerja ritel pada Bintaro Plaza dan Lotte Mall terutama terkait intensitas pengunjung, volume penjualan dan omzet pasca operasionalisasi BXC.

2. Berdasarkan hasil analisis komparatif diketahui bahwa terdapat perubahan pola belanja konsumen antara di Bintaro Plaza dan Lotte Mall terutama pasca operasionalisasi BXC. sementara itu bila melihat perubahan pola belanja konsumen antara Bintaro Plaza, Lotte Mall dan BXC terdapat perbedaan yang cukup signifikan. Sebagian besar konsumen Lotte Mall (70,88\%) berpindah belanja ke pusat perbelanjaan lain, yaitu 38,17\% pindah ke Mall BXC dan $32,71 \%$ pindah ke Bintaro Plaza dan lainnya. Hal yang sama terjadi di Bintaro Plaza dimana sebagian besar konsumen (76,30\%) berpindah belanja ke pusat perbelanjaan lain, yaitu 53,91\% pindah ke Mall BXC dan 22,39\% pindah ke Lotte Mall dan lainnya. Sementara kemampuan Lotte Mall untuk menarik konsumen dari pusat perbelanjaan lain (dari Bintaro Plaza dan lainnya) sebesar 23,96\%. Sedikit lebih rendah terjadi di Bintaro Plaza dimana kemampuan menarik konsumen dari pusat perbelanjaan lain (dari Lotte Mall dan lainnya) sebesar 14,29\% dan hanya sebagian kecil konsumen Lotte Mall $(5,16 \%)$ dan Bintaro Plaza $(9,41 \%)$ yang tidak pindah ke pusat perbelanjaan lain pasca operasionalisasi Mall BXC.

3. Berdasarkan hasil analisis diketahui bahwa terdapat hubungan yang cukup kuat antara perubahan kinerja ritel dengan perubahan pola belanja konsumen. Hal ini dapat dilihat dari:

- Perubahan pola belanja konsumen terbukti memiliki hubungan yang signifikan dengan perubahan intensitas pengunjung ritel, dengan besarnya hubungan sebesar 97,3\% (sangat kuat);

- Perubahan pola belanja konsumen terbukti memiliki hubungan yang signifikan dengan perubahan omzet pelaku ritel, adapun besarnya hubungan sebesar 98,9\% (sangat kuat); 
- Perubahan pola belanja konsumen tidak memiliki hubungan yang signifikan dengan perubahan volume penjualan ritel, dimana besarnya hubungan hanya sebesar $65 \%$ (sedang).

4. Berdasarkan hasil analisis korelasi dapat disimpulkan bahwa terdapat hubungan antara penilaian konsumen terhadap pusat perbelanjaan dengan perubahan pola belanja. Hubungan antara perubahan pola belanja konsumen dengan penilaian konsumen terhadap 12 aspek pusat perbelanjaan yaitu dapat dijelaskan sebagai berikut:

- Perubahan belanja harian konsumen terbukti memiliki hubungan yang signifikan dengan hanya 5 variabel penilaian konsumen pada aspek perencanaan, desain, anchortenant, marketing dan management pusat perbelanjaan.

- Perubahan belanja bulanan konsumen terbukti memiliki hubungan yang signifikan dengan 6 variabel penilaian konsumen pada aspek ukuran, perencanaan, desain, branding, management dan layanan konsumen pusat perbelanjaan.

- Perubahan belanja pakaian, belanja kuliner, belanja lifestyle, dan belanja rekreasi konsumen terbukti memiliki hubungan yang signifikan dengan penilaian konsumen pada semua aspek pusat perbelanjaan (lokasi, visibilitas, aksesibilitas, ukuran, perencanaan, desain, anchortenant, tenancymix, branding, marketing, management, dan layanan konsumen).

\section{Saran}

Saran atau rekomendasi yang dapat diberikan kepada beberapa pihak terkait yaitu:

1. Rekomendasi bagi pengembang pusat perbelanjaan baru

Hasil penelitian memperlihatkan bahwa penilaian konsumen terhadap 12 aspek pusat perbelanjaan memiliki hubungan tidak langsung dengan perubahan kinerja pelaku ritel. Oleh karena itu, seyogyanya para pengembang pusat perbelanjaan ketika akan mengembangkan pusat perbelanjaan baru, perlu memperhatikan 12 aspek yang meliputi lokasi, visibilitas, aksesibilitas, ukuran, perencanaan, desain, anchortentant, tentancymix, branding, marketing, management dan layanan konsumen.

2. Rekomendasi bagi pengelola pusat perbelanjaan yang sudah ada

Hasil penelitian memperlihatkan bahwa operasional pusat perbelanjaan baru sedikit/banyaknya memiliki dampak terhadap pelaku ritel di pusat perbelanjaan eksisting. Oleh karena itu, dalam konteks pusat perbelanjaan eksisting, perlu melakukan adaptasi inovatif untuk mampu tetap berkompetisi dengan pusat perbelanjaan baru. Proses adaptasi inovatif tersebut, dilakukan melalui review dan repositioning konsep pusat perbelanjaan dengan memperhatikan 12 aspek pusat perbelanjaan yang dinilai konsumen. Walaupun demikian, ada hal-hal dari 12 aspek tersebut yang tidak dapat diubah oleh pengelola pusat perbelanjaan, yaitu lokasi dan aksesibilitas.

3. Rekomendasi bagi pemerintah daerah setempat

Hasil penelitian memperlihatkan bahwa pengembangan pusat perbelanjaan, di satu sisi menghadirkan kompetisi antar pelaku ritel yang semakin kuat dan di sisi lain juga menghadirkan perubahan pola belanja konsumen. Kedua hal tersebut dapat bersifat positif namun juga dapat bersifat negatif. Oleh karena itu, diperlukan upaya menjaga tingkat kompetisi pelaku ritel dan pola konsumsi masyarakat dalam tingkat yang wajar. Pemerintah daerah setempat diharapkan dapat mengatur dan mengendalikan kuantitas dan sebaran pusat perbelanjaan tanpa melampaui kebutuhan pelayanan. Dalam hal pengaturan, sudah tersedia pengaturan pada skala nasional untuk mengatur hal ini dalam Peraturan Presiden Republik 
Indonesia Nomor 112 Tahun 2007 tentang Penataan dan Pembinaan Pasar Tradisional, Pusat Perbelanjaan dan Toko Modern. Sebagai tindak lanjutnya, maka Pemerintah Daerah perlu mengatur dalam skala lokal dalam bentuk Perda yang memuat kondisi spesifik setempat. Selain pengaturan, Pemerintah Daerah setempat juga perlu melakukan penertiban/penegakan peraturan, agar tercapai kondisi yang diinginkan (ideal) dalam konteks pelayanan pusat perbelanjaan yang optimall.

4. Rekomendasi bagi penelitian lebih lanjut

Disadari bahwa penelitian yang dilakukan ini masih terfokus pada perubahan kinerja pelaku ritel dan perubahan pola belanja konsumen pada pusat perbelanjaan. Dalam perspektif yang lebih luas, masih ada beberapa jangkauan penelitian yang dapat dilakukan lebih jauh. Rekomendasi topik bagi penelitian lebih lanjut yaitu:

- Studi perubahan kinerja pengelola pusat perbelanjaan eksisting di sekitar yang dipengaruhi perubahan kinerja ritel dan perubahan pola belanja konsumen pasca operasionalisasi pusat perbelanjaan baru;

- Studi pengaruh jarak dan jenis usaha ritel terhadap perubahan kinerja ritel dan perubahan pola belanja konsumen pada pusat perbelanjaan eksisting pasca operasionalisasi pusat perbelanjaan baru.

\section{DAFTAR PUSTAKA}

Farchan, T. (2016). Analisa Sosial Ekonomi Pembangunan Pusat Perbelanjaan Modern: Studi Kasus Pembangunan Lotte Mall Di Kecamatan Pondok Aren Tangerang Selatan 2010. Jurnal Renaissance, 5(16): 1-10.

Ghei, N. (2012). Opening Speech. India Shopping Centre Forum, May 8-9 2012, Mumbai.

Levy, M. \& Weitz, B. A. (2008). Retailing Management. New York: McGraw-Hill Irwin.

Manser, M. H. (1995). Oxford Learner's Pocket Dictionary. Oxford: Oxford University Press.

Neo, L. W. K. \& Wing, T. K. (2005). The 4Rs of ASIAN Shopping Center Management. Singapore: Marshall Cavendish Academic.

Peraturan Presiden Republik Indonesia Nomor 112 Tahun 2007 tentang Penataan dan Pembinaan Pasar Tradisional, Pusat Perbelanjaan dan Toko Modern.

Stillerman, J.\& Salcedo, R. (2012). Transposing the Urban to the Mall: Routes, Relationships, and Resistance in Two Santiago, Chile, Shopping Centers. Contemporary Ethnography, 41(3): 309-336. 